\section{Strategic Planning and Management of Food and Agribusiness Chains: The ChainPlan Method (Framework)}

\author{
Marcos Fava Neves ${ }^{1}$ \\ ${ }^{1}$ University of São Paulo and Fundação Getulio Vargas, São Paulo, Brazil. \\ Rafael Bordonal Kalaki ${ }^{2}$ \\ ${ }^{2}$ University of São Paulo and Socicana, Ribeirão Preto, Brazil
}

Jonny Mateus Rodrigues ${ }^{3}$

${ }^{3}$ University of São Paulo, Ribeirão Preto, Brazil

Allan Wayne Gray ${ }^{4}$

${ }^{4}$ Purdue University, West Lafayette, USA

\begin{abstract}
Purpose - The objective of this paper is to improve the method for the strategic planning and management of food and agribusiness chains.

Design/methodology/approach - Several research methodologies are used to develop the ChainPlan methodology. The theory (literature review) provided the basis on which to build a preliminary framework ten years prior. Then, empirical application of the initial method provided insights regarding needed additions to and subtractions from the original method. These insights, combined with continued research on advances in the theories, contributed to further development of the ChainPlan methodology
\end{abstract}

Findings - A method is proposed to fill the theoretical gap regarding the strategic planning applied to agribusiness chains. The ChainPlan method is a theoretical-empirical method, built based on the academic literature and perfected over the years through its application in several productive chains

Originality/value - Many authors have proposed a method to build strategic plans in organizations, but when planning agribusiness chains is concerned, the academic discussion revolves around the coordination of agribusiness chains and analyses to be applied in this sector. This article fills this theoretical gap and proposes a tool, which is a specific strategic planning method to be applied in agribusiness chain

Keywords - strategic planning and management, agribusiness, systems
Received on

12/12/2017

Approved on

02/05/2019

Responsible editor:

Prof. Dr. João Maurício Gama

Boaventura.

\section{Evaluation process:}

Double Blind Review

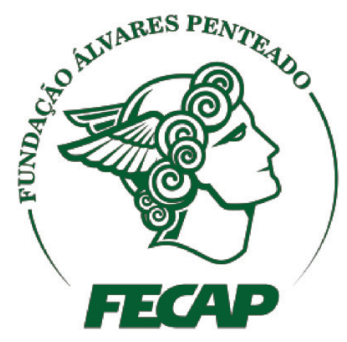

Review of Business Management 


\section{Introduction}

The growing global demand for food resulting from factors such as population growth, the economic development of populous nations, income distribution, and urbanization has persisted over the last ten years. Important changes have taken place in the agribusiness sector to drive efficiency in the various global food networks. On the other hand, the dramatic rise in the global demand for biofuels continues to increase the pressure on grain and sugar production, agricultural land use, and other agribusiness functions. Consequently, many agribusiness chains are not prepared for this continued growth. To face these changes in the international business environment and increase opportunities for food and biofuels agribusiness chains, careful systematic strategic planning is essential (Neves, 2005).

Neves (2008) developed a preliminary method for strategic planning and management of food and agribusiness chains based on demands for projects starting in the early 2000s. From 2008 to 2018 (10 years), several food and agribusiness chains in different countries applied this method. These applications provided distinct contributions to the preliminary method, creating the need to improve and update the method. This article describes the improved food and agribusiness chains strategic planning and management method (ChainPlan), based on several empirical applications, the most recent literature on agribusiness chains, and practical contributions provided by the private sector.

There is an absence in the current literature of a common theoretical framework in regard to value chains. This makes it impossible for generalizations to be made based on the different analyses and, thus, does not allow for comparisons between models (Clay \& Feeney, 2019). The ChainPlan method seeks to help fill this gap by generating a replicable model that can be used to compare the most diverse value chains, allowing for a better understanding of the indicators needed to measure and evaluate competitiveness and performance in agribusiness chains.

The article continues in the second section with the literature review that contributed to ChainPlan, the third section outlines the methodology used to build the ChainPlan method, and the fourth section presents the ChainPlan sequence of steps used to build a strategic plan and, finally, the managerial implications.

\section{Literature Review}

\section{I Agribusiness systems, chains, clusters, and networks}

In the agribusiness context, numerous theories from the literature contribute to the analysis of food chains: Agribusiness Systems, Clusters, Networks, Supply Chains, Interorganizational Relationships and Netchains, Transaction Cost Economics, Institutions, Collective Actions, and others. Davis and Goldberg (1957) started the studies in agribusiness, developing the concept (business that involves agriculture) and the theory of the Commodity System Approach (CSA). In the eighties, Morvan (1985) and others advanced Davis and Goldberg's (1957) concepts and developed the theory of Filière Agroalimentaire.

An Agribusiness System is a macro analysis of a food product flow from suppliers (of inputs such as seeds, chemicals, and others), farmers, agro-industry, and distribution towards final consumers, comprising the following key elements for its descriptive analysis: agents, relationships between them, sectors, supporting organizations, and the institutional environment (Batalha, 2009; Zylbersztajn \& Neves, 2000).

While the network comprises vertical, lateral, and horizontal relationships between independent entities, the production system emphasizes vertical relationships. Ménard (2002, p. 4) explains that "a network is a hybrid form of governance, and what is called an agribusiness system is a special case of a network." However, Beers, Omta, and Trienekens (2001, p. 2) state 
that "networks are seen as the total number of agents within an industry and/or between related industries, which can potentially work jointly to add value to customers." Therefore, the theoretical model of the company's network does not consider pure self-interest as the determinant of behavior; network theory emphasizes the normative and social structures in which exchanges are embedded (Watson, Worm, Palmatier, \& Ganesan, 2015).

The analysis of a network in which a focal firm operates is important in rapidly changing business environments that demand flexible, associative networks of functionally specialized firms, fused by cooperative relationships that provide access to unique knowledge and resources (Wang, Gu, \& Dong, 2013).

Network theory provides an excellent framework to understand how changes in one part of the channel ecosystem affect other parts, such as the propagation of inter-firm behaviors from one channel relationship to an adjacent one (Watson et al., 2015).

Lazzarini, Chaddad, and Cook (2001) integrate network and system concepts in an approach called netchains. The integration of these concepts enables organizational interdependencies within the network, different mechanisms of coordination (management plans, standardization of process, and adjustments) and sources of value (operation and production optimization, transaction cost reduction, diversity, and cospecialization of knowledge). Within a company network, the way the industry relates to its producers and distribution channels gives rise to the concept of a strictly coordinated agribusiness subsystem that was proposed by Zylbersztajn and Farina (1999). A subsystem must offer a product that meets the final consumer's expectations. Thus, it is essential to manage the transactions between the links of the subsystem. In addition, producers can develop horizontal alliances to increase their bargaining power and explore gains from collective action, which in a subsystem become an important aspect of coordination (Zylbersztajn \& Farina, 1999).
The way organizations gain and use their power and balance asymmetrical dependence determines channel structures and performance (Antia, Zheng, \& Frazier, 2013). As social exchange theory suggests, power refers to the ability to influence channel partners to take actions they would not take otherwise (Draganska, Klapper, \& Villas-Boas, 2010). Power does not necessarily induce conflict; it is the nature and sources of power that can aggravate the negative effects of conflict on channel performance by increasing perceived unfairness (Samaha, Palmatier, \& Dant, 2011).

In essence, the idea of company networks involves a level of analyses centered on one company that forms its network of distributors, suppliers, and others. Agribusiness systems and chains refer to the groups of companies that act in certain business flows. A coffee company builds its own network, and all these networks together make the coffee agribusiness system or coffee chain. The ChainPlan method described here focuses on the chain (or system) level for a certain region's poultry chain, coffee chain, orange juice chain, etc.

\subsection{Transaction cost economics and contracts}

Transaction cost economics (TCE) and contract theory literature contribute to the construction of the ChainPlan method. Coase (1937) states that a company is a nexus of contracts. Williamson (1985) also claims a company has a governance (management) mechanism that ranges from arm's length transaction markets (pricing systems) to full vertical integration. When market failures create excessive costs, companies will choose vertical integration over market transactions to source or sell (Rindfleisch $\&$ Heide, 1997). With vertical integration, the organization owns various elements in the value chain. Different theoretical perspectives indicate distinct advantages of this strategy, but typically, the benefit hinges on lowering the costs associated with channel exchanges (Watson et al., 2015). 
According to TCE, a vertically integrated firm may reduce costs incurred by bottlenecks in production and increase efficiencies, particularly in the presence of a market failure (Arya \& Mittendorf, 2011).

Hill (1990) states that by considering economic transactions in a wider context it is possible to observe that the invisible hand of the market favors cooperative actors whose behaviors are biased toward cooperation rather than opportunism. Heide, Rokkan, and Wathne (2007) proposed to examine the effects of monitoring on inter-firm relationships, and whether opportunism increases or decreases when using monitoring as a mechanism of control. Likewise, the punishment of one member in a distribution network can reduce opportunism by intermediaries that observe that punishment through both a deterrent effect and a trustbuilding process (Wang et al., 2013).

TCE recognizes uncertainty as exogenous disturbances affecting transactions (Zylbersztajn, 1996). According to Farina, Azevedo, and Saes (1997), uncertainty creates unforeseen circumstances that contracts between parties cannot cover.

For Lusch and Brown (1996) and McNeil (1974), contracts are mechanisms that regulate transactions and are used to reduce risks and uncertainties in exchange processes. Within this view, contractual arrangements can solve some coordination problems but can also create others.

In agribusiness systems, coordination between input suppliers, producers, and industry is part of a vertical coordination of production, which can be improved with the design of contractual arrangements that minimize transaction and production costs between agents from inputs to the final consumer. Similarly, if there are joint action gains between agents of the same link, there may be better horizontal coordination of production, allowing the formation of associations and cooperatives to develop these actions.

For Zylbersztajn and Farina (1999), incentive mechanisms are instruments that combine the self-interest of members with the goals of the organization: by pursuing their own goals no matter what they are, the member ends up helping the organization to achieve its own.

Chaddad and Rodriguez-Alcalá (2010) attempted to analyze inter-organizational relationships in agri-food systems from a TCE perspective and their efficiency relative to alternative forms of organization, in particular, markets and hierarchies (internal organization).

However, recent TCE-based research has expanded the scope of related constructs to include not just opportunism (Jap, Robertson, Rindfleisch, \& Hamilton, 2013; Wang et al., 2013) but also contexts (Kim, McFarland, Kwon, Son, \& Griffith 2011), culture (Steenkamp \& Geyskens, 2012), and online business environments (Chintagunta, Chu, \& Cebollada, 2012).

Over the past 30 years, transaction cost economics and contract theory have proven to be very useful to agribusiness systems/chains. These theories have a strong influence on the ChainPlan method described here.

\subsection{Collective actions in agribusiness systems}

Collective action theory is an important component of the ChainPlan method. Collective actions are social interactions that involve a group of individuals who pursue common interests that require joint actions, performed collectively rather than individually (Nassar \& Zylbersztajn, 2004). Thus, individuals have common needs that can only be met through joint actions.

Olson (1999) was the first author to establish an economic explanation for social group formation. With respect to collective action, the author states that groups provide collective goods and their existence is undermined due to the presence of free riders. Cook and Iliopoulos (2016) also addressed free riders in their study and state that the tendency for free riding has created significant challenges for continued joint collaboration between and among member patrons. 
Contemporary research also examines the role of internet-based communication systems that promote cooperation among employees or help to build relational capital in inter-firm distribution networks (Spralls, Hunt, \& Wilcox, 2011). Communication systems can build networks that are more integrated by increasing trust and communication quality, which in turn helps to facilitate collective action and drive exchange performance. By examining only one dyadic channel partnership one can miss the influence of the overall network of relational ties in which that dyad is embedded (Wang et al., 2013).

For Sacomano and Truzzi (2004), the relationships rely on trust, reciprocity, and cooperation between members. Involved organizations can be influenced by collective actions in many aspects such as changes in the system, in the structure, and even in the organizational culture. Trust is vital for successful collective actions.

Buzzell and Ortmeyer (1995) claim it is essential that agents who seek to succeed in their collective actions share resources and that top management commits to the consequences and demands of integration. This provides resources that are often valuable, rare, and imperfectly imitable and can be leveraged to create sustainable competitive advantages (Kozlenkova, Samaha, \& Palmatier, 2014). The resource-based theory can inform various collective actions of the chain, including the adoption of a valuable new sales channel, distributor acquisitions of rare information (Guo \& Iyer, 2010), inimitable supply chain service technologies (Richey, Tokman, \& Dalela, 2010), and the augmentation of organizational capabilities by using retail category captains (Nijs, Misra, \& Hansen, 2013). Agents of an agribusiness system have a multitude of strategic opportunities to use collective actions to create vertical chains with superior performance.

Low levels of conflict potentially increase performance, but increasing conflict can hasten the demise of the relationship and damage channel performance. In particular, it undermines cooperative actions and prompts the damaged party to seek other trade partners (Watson et al., 2015). Unsurprisingly, research on channel conflict, its outcomes, how it arises, and how it can be mitigated has been of longstanding interest to marketing channels strategy (Goetz, Krafft, Mantrala, Sotgiu, \& Tillmans, 2015). The velocity or rate and direction of change of a relationship commitment have a strong and significant impact on performance, going beyond the impact of any static level of commitment (Palmatier, Houston, Dant, \& Grewal, 2013). Agents of an agribusiness system must be aware of the potential for conflicts among chain participants and have a clear conflict management plan.

Collective actions are present in agribusiness system activities in several forms such as associations, cooperatives, alliances, and others, and even building a strategic plan for a whole system/chain is a process of collective action. The ChainPlan, in essence, is a collective action.

\subsection{Strategic management methods, strategic planning, and marketing plans}

Several definitions and concepts of strategy exist in the literature, some with complementary views and others with divergent views. In this regard, Besanko, Dranove, and Shanley (2000) state that many definitions have common phrases such as "long term goals and policies," which suggests that strategy is related to the decisions that a company makes and the consequences of their success or failure. It is possible to point out other contributions in this field from the studies by Andrews (1987), Ansoff (1965), Chandler (1962), Digman (1990), Henderson (1984), Mintzberg, Quinn, and James (1988), Moore (1993), and Pearce and Robinson (2014).

Over time, several authors have proposed methods for organizations to perform their strategic and marketing planning. In this study, we conducted a review of nine different methodological proposals for strategic planning in 
order to develop the method proposed. The studies include: Campomar (1982), Gilligan and Wilson (2002), Jain (2000), Kotler (2000), Lambin (2012), Las Casas (1999), Oliveira (2006), Pearce and Robinson (2014), Silva and Batalha (2010), Soriano, Torres, and Rosaleń (2010), Westwood (1995), Wood (2004), and Wright, Kroll, and Parnell (2000). Since ChainPlan is a strategic planning method, these theories are fundamental to the method. We incorporate contributions from these authors throughout the ChainPlan method.

\section{Methodology used}

We employ several research methodologies to develop the ChainPlan method. The theory (literature review) provided the basis on which to build a preliminary framework for the Strategic Planning and Management of Agribusiness Systems/Chains ten years prior. Then, empirical application of the initial method provided insights regarding necessary additions to and subtractions from the original method. These insights, combined with continued research on advances in the theories highlighted in the literature review, contributed to further development of the ChainPlan methodology.

The starting point for building a chain planning methodology originated from the demand at the beginning of this century to build a plan for the orange juice chain in Brazil, established by the Brazilian Association of Citrus Exporters (Abecitrus). After this first empirical study concluded with success, demands from other agents and organizations from different food and agribusiness systems/chains emerged. In total, 9 chains have empirically tested the ChainPlan method, including: the orange chain
(2004, 2007, and 2010), wheat chain (2005), milk chain (2007), sugar cane chain (2009 and 2014), beef chain (2011), cotton chain (2011, 2013, and 2017), flower chain (2014), pork chain (2015), and vegetables chain (2017).

In each of these applications, new insights were obtained and the preliminary method gained more sophistication. In addition to the Brazilian chains, the method has been applied in the wheat chain in Uruguay (2007) and milk, soybean, and beef chains in Argentina (2007, 2010, and 2014). In addition, others beyond the initial creators have applied the method, including applications in South Africa and other countries. The authors received valuable feedback from these international users and incorporated their insights to make the method more internationally robust. The new ChainPlan method presented in the next session is very different from its original sequence and is now the result of applications in several different businesses and environments. Throughout the remainder of the paper, the term chain is synonymous for systems.

\section{ChainPlan:AMethod forStrategic Planning and Management of Food and Agribusiness Chains}

The strategic planning of a chain starts with some participant having the initiative to build a plan. It can derive from a demand from existing sectorial organizations, together with the government, universities, and research institutes willing to organize a planning process and a future vision for the chain.

The ChainPlan method (framework) is composed of a twelve-stage process, described in the following parts (Figure 1). 


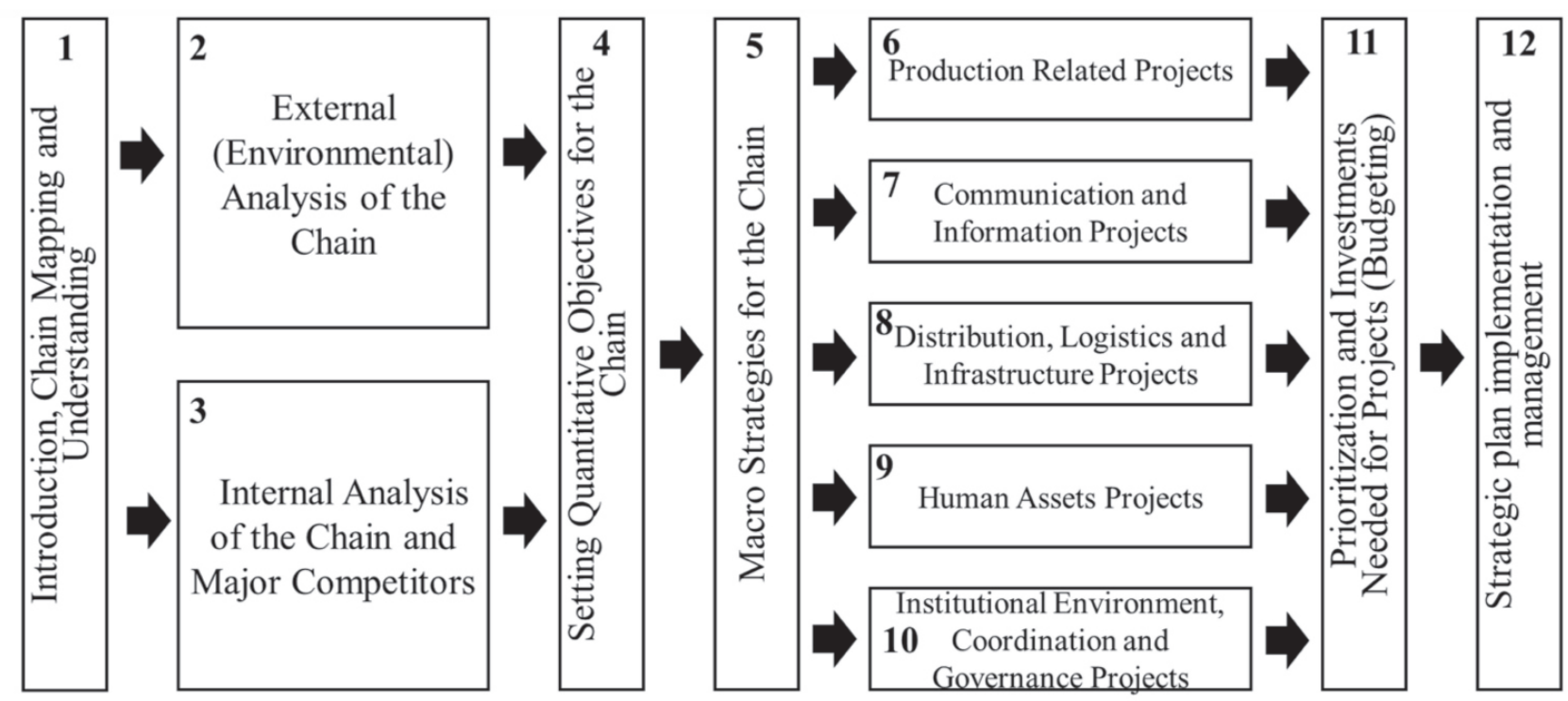

Figure 1. ChainPlan - stages for the strategic planning and management of food and agribusiness chains.

Next, we provide analysis suggestions and proposals for each of the 12 steps of the ChainPlan methodology. These suggestions will lead to strategic projects being executed by chain participants to fulfill the resulting strategic plan.

\section{Stage 01 - Introduction, Chain Mapping, and Understanding}

Stage 1 begins with initial contact with the principals of the agribusiness chain. Several steps should be pursued at this stage:

a) build the team that will participate in the planning process;

b) identify any previously developed plans for the chain and study them. Alternatively, interview the participants to understand their current chain planning process. In the case of an existing sophisticated planning process, an examination of how ChainPlan can enhance the existing model and a plan for adapting it gradually to the proposed system should be considered;

c) search for plans drawn up for similar agribusiness chains in other countries;

d) search for research organization, government, and private sector materials and publications on important topics related to the chain; e) identify the main specialists in the production chain;

f) elaborate a first description (design) of the chain using boxes, reflecting the flow of products from inputs until the final consumer. With this first version of the description, carry out in-depth interviews with executives of companies operating in the sector and other specialists (researchers, sector leaders, and others) to adjust the proposed design. Also conduct a careful bibliographic review of recent dissertations and theses, in addition to articles in academic magazines and papers, or other general publications;

g) try to measure the size of the chain, searching for data about all the industries involved in order to know its size, contribution to GDP, to employment, to tax collection, and others. Interviews with specialists will contribute significantly to these measures. At this point, all data obtained are processed to come to an estimate of the size of the chain in the previous year. Then data can be sent to participating companies to validate and give comments and contributions. 


\section{Stage 02 - External (Environmental) Analysis of the Chain}

According to Lambin (2012), for longterm success, an organization must focus on the ability to anticipate market changes and adapt to these changes. Thus, analyzing the organization's external environment is critical. The second stage of ChainPlan focuses on developing a deep understanding of the macro-environment of the chain. The following analyses are suggested:

a) examine market data and trends for the chain's products (production, consumption, exports, imports, trade, prices, and others);

b) build a chain information system, looking for national and international quantitative and qualitative data;

c) understand the main competitors and their strategies;

d) understand the trade barriers (tariff and non-tariff) and check collective actions to reduce them;

e) analyze consumer behavior, buying decision processes, and trends;

f) identify the threats and opportunities arising from uncontrollable variables (possible changes in political/legal, economic, natural, socio-cultural, and technological environments), both in domestic and international markets, including labor, technology, innovation, consumers, and others;

g) develop a scenario matrix combining the most important factors from the opportunity and threat analysis to develop a series of possible industry outcomes over the next ten years.

\section{Stage 03 - Internal Analysis of the Chain and Major Competitors}

A critical analysis of the chain is a fundamental factor in the strategic planning process, since among other advantages it allows for the identification of strengths and weaknesses and proposes actions to leverage strengths and mitigate weaknesses. For this third stage, we suggest the following activities:

a) identify the main producing regions for the core product, including particularities and trends;

b) map the contracts and existing forms of coordination;

c) map, analyze, and understand possible substitute products;

d) evaluate public policies and incentives in the chain;

e) describe existing governance structures and the characteristics of transactions;

f) analyze the competitiveness of the chains. Use tools such as Porter's five forces analysis, Porter's diamond analysis, and key success points;

g) analyze chain value creation and resource skills;

h) analyze critical success factors of the chain;

i) select, among other countries' chains (that may or may not be competitors), sources of benchmarks;

j) identify all the strengths and weaknesses of the chain (consider topics that appear in stages 6 to 10 as well).

\section{Stage 04 - Setting Quantitative Objectives for the Chain}

According to Neves (2008), the proposed objectives must be clear and quantifiable, so that agents of the chain can monitor the results obtained. Thus, after analyzing the external and internal environment, the main quantitative objectives for the next ten years should be developed. Suggestions for objectives include: production, consumption, exports, imports, sales, GDP generated, costs, employment created, taxes collected, and others. A table with numbers for the next ten years would be the output at this stage. Ideally, this table will factor in the scenario analysis and include expected, worst, and best cases. 


\section{Stage 05 - Macro Strategies for the Chain}

In this stage, it is suggested that a list is made of the main strategies (actions) to be used to achieve the objectives proposed in stage 4 , in terms of leadership, positioning, value capture, and market segmentation. Traditional authors and theories can contribute, such as Porter's (1980) generic strategies, concepts of the resource-based view from Wernerfelt (1984), Prahalad and Hamel's (1990) core competencies, the BSC view from Kaplan and Norton (1992), Lafley and Martin (2013), and other authors dealing with general strategies. We address details of these general strategies in stages 6 to 10 .

\section{Stage 06 - Production Related Projects}

Stage 6 focuses on production related strategies. To propose projects related to production, the following areas are suggested:

a) analyzing production processes and production capacities;

b) mapping and planning production risks (sanitary and others);

c) areas for expanding production;

d) smart production concepts;

e) circular economy concepts and integrated production systems;

f) financing of investments (public credit, role of capital markets, private sources such as barter, or other forms of financing) and special lines for smallholders;

g) insurance (income, environmental issues, and other risks) and price policies (minimum prices and other discussions);

h) irrigation incentives and policies;

i) adopting a vision of continuous product improvement;

j) products and product lines as well as complementary product lines for expansion decisions and added value opportunities;

k) identifying innovation opportunities in the chain, stimulating start-ups and other forms;
1) research and development issues and ideas, partnerships with universities, research institutes, and other organizations (role of public sector);

m) analyzing partnerships for complementary solutions;

n) services that are being and will be offered;

o) brands, country of origin, labeling, logos, and others;

p) sustainability, renewable sources of energy, and certification processes (carbon, water, and other "footprints"), climate related issues, payment for environmental services, and biodiversity related issues;

q) long term analysis and competitiveness of inputs (crop protection, fertilizers, lime, machinery, genetics, equipment, software, and others);

r) adapting products to standards and institutional environment;

s) packaging (labels, materials, and design).

\section{Stage 07 - Communication and Information Projects}

Stage 7 focuses on strategic communication and information plans. To propose projects related to information and communication, some actions are suggested:

a) build a chain information system, establishing information that will be collected and distributed to enhance chain transparency;

b) build the information distribution systems using appropriate media platforms;

c) address connectivity and access to digital services;

d) build a chain communication plan, identifying the target audiences that will receive the communication (messages); develop the desired goals for this communication (product knowledge, product reminders, persuasion, among others); try to achieve positioning and convey message of products generated by the chain; set the content of communication that will be used, i.e., 
define the advertising plans, public relations and publicity, sales promotion, among others;

e) establish a benchmark of films and international materials used by other agribusiness systems;

f) indicate how communication results will be measured so that the system can learn to use the best tools and achieve return on investment; tell the story;

g) establish a chain identity, brand, and image;

h) create joint symbols and certifications;

i) create institutional communication material for the chain (including benefits, contributions, advantages, strengths);

j) create specific communication campaigns for the foreign market, direct consumers, influencers, facilitators, and the general public;

k) communicate the benefits of the chain in terms of sustainable inclusion, tax generation, and other contributions (e.g. impact on GDP and employment);

l) establish relationship programs with NGOs and other chain influencers (medical and nutritional areas, the media, and young people, among others);

m) consider the role of government agencies in promoting communication activities.

\section{Stage 08 - Distribution, Logistics, and Infrastructure Projects}

Stage 8 focuses on distribution, logistics, and infrastructure projects needed to strengthen the chain's physical connections between participants. To propose projects related to distribution and logistics, some actions are suggested:

a) analyze the logistics of the entire chain and possibilities for improvement (modal integration, rural roads, logistical hubs, and others);

b) analyze storage capacities and needs;

c) analyze the distribution channels of products and seek new ones, setting distribution objectives such as presence in markets, type and number of points of sale, services to be offered, market information, product promotion, and incentives;

d) identify the possible wishes of international distributors and consumers to adapt the services provided;

e) search for improvements in infrastructure;

f) examine concepts of the sharing economy (models like Uber) that could be used by the chain;

g) identify collective actions that could be carried out in international markets;

h) identify synergies with other food chains;

i) design international strategies for exports such as franchising, joint ventures, or other contractual forms, or even vertical integration;

j) consider the critical role of governments in logistics (financing, data management, governmental structures, privatization, public private partnerships, and others) and in promoting competition and free markets for transport services;

k) leverage favorable government agencies to promote access to international markets (agreements, trade zones, and others);

\section{Stage 09 - Human Assets Projects}

The resource-based view of strategy makes a compelling argument that strategic success correlates strongly to human capital. Similarly, a chain's success relies on human capital. This is the focus of stage 9 of the ChainPlan method. To propose projects related to human resources, some actions are suggested:

a) examine critical labor issues, labor laws, rural labor retirement programs, and potential improvements;

b) conduct an analysis of educational needs, incorporating a holistic view of educational needs and offerings at all levels (municipal, state, and federal);

c) design training strategies for production, manufacturing, quality, safety, sustainability, and management for 
participants in the agribusiness chain to gain efficiency and enhance innovation;

d) identify programs for rural schools;

e) develop a chain education platform, with topics, institutions, and responsibilities;

f) promote extension services and programs;

g) leverage the role of universities and technical schools;

h) develop distance education programs;

i) leverage the role of associations, cooperatives, federations, and other organizations;

j) create communication plans to increase awareness of employment opportunities in the chain, attract and retain talent in the industry, and create public support for human capital in the industry.

\section{Stage 10 - Institutional Environment, Coordination, and Governance Projects}

Michael Porter's work on external analysis suggests that industry incumbents do not have to passively accept the external environment they face. There are opportunities to act to affect change in the industry environment. He acknowledges that this strategy is often most successful when there is collective action by participants in the industry. Stage 10 of ChainPlan addresses the collective actions needed to create the best possible external environment for the chain. To propose projects related to this topic, the following areas for action are suggested:

a) public and private credit projects;

b) the role of government, agencies, and other public institutions;

c) the role of cooperatives, associations, and other collective organizations;

d) taxes, policies, and incentives;

e) regulatory issues (harmonization, natural resources, safety, product registration, environment, licenses, forestry codes, water resources and protection, storage, land acquisition, and others);

f) security and crime related topics;

g) land ownership, land rights, and issues linked to minorities; h) chain code of conduct and chain dispute resolution mechanisms;

i) reducing bureaucracy;

j) projects to increase consumption;

k) sanitary and certification issues;

l) project for tax reduction in the agribusiness system;

m) projects for trade and investment;

n) equipment import incentives;

o) trade policies and negotiations;

p) standardization of products and product names;

q) modernization and transparency in legislation;

r) public and private conflict resolution systems with proposals for coordination and contracts;

s) public services driven by needs of the private sector.

\section{Stage 11 - Prioritization and Investments Needed for the Strategic Projects (Budgeting)}

In this stage, all projects generated in stages 6 to 10 need formal project descriptions including an analysis and description of objectives, actions, implementation suggestions, performance indicators, inter-relations, teams, deadlines, budgets, and forms of management.

After the projects are detailed, it is necessary to prioritize them. According to Rodriguez (2016), the difference between the success and failure of an organization lies in strategic and operational prioritization. Prioritization increases the success rate because it increases the focus of the team, builds an execution mentality, and signals what matters.

Prioritization can be done in a chain workshop, in order to reach a democratic decision, using the criteria of urgency (should be done immediately, related to time), relevance (related to the potential positive impacts), relatedness (related to how projects are connected to and reinforce impacts), and investment (related to the amount of resources needed). The ones that receive the highest ratings for relevance, urgency, 
and relatedness, combined with the lowest investment required, receive the highest priority.

Having prioritized the set of projects, budgets should be prepared for all of the projects along with the total budget of the strategic plan to decide what projects to execute. Here it is suggested that the prioritized projects are executed in waves, allowing the most urgent ones to be executed first while securing funds for the next wave of projects.

\section{Stage 12 - Strategic Plan Implementation and Management}

An effective strategic planning process is one that is appropriate for the organization and the situation in which the organization finds itself. When implemented correctly, with the right leadership, motivation, policy, and management, the strategic results are highly successful (Klag \& Langley, 2014). Implementation is at least as important as building the strategic plan for the chain; in other words, success comes when the chain makes it happen rather than when it develops the plan. To implement a strategic plan, some authors such as Backer (2003), Rigby and Bilodeau (2015), David (2002), Grant (2010), Guerreiro and Souza (2015), Kaplan and Norton (1997, 2004, 2008), Mintzberg (1994), and Thompson and Strickland (2000) have proposed some actions. In addition to these actions and the previous applications of the methods, we suggest the following for strategic plan implementation:

a) develop a governance structure and an implementation process;

b) evaluate and adapt the resources;

c) involve different levels and agents in the execution process to achieve alignment across agents in the chain;

d) build and motivate the teams for the strategic projects;

e) define goals and objectives for people;

f) build a committee to discuss specific issues and solve problems;

g) seek public-private partnerships;

h) communicate the plan to the different organizations and agents involved; i) review the ChainPlan constantly.

Typically, agribusiness chains present some horizontal associations (such as associations of farmers, processing industries, etc.) that play important roles in the ChainPlan. It is hard to find a vertical organization (uniting different stages of the chain) that involves all agents. A vertical organization can help implement the ChainPlan, but existing applications of ChainPlan have not all resulted in the development of a vertical organization. Nonetheless, a vertical organizing unit could help in many important ways, including:

a) organizing, collecting, storing, and exchanging information;

b) organizing and planning forums for discussing strategies;

c) creating flexibility to capture and use resources that individual agents in the chain might not have;

d) facilitating a unified voice in the agribusiness chain and representation in institutions;

e) guiding a positive agenda for the chain;

f) building and implementing plans.

Recent research also addresses actions within vertical relationships, such as multilateral bargaining across channel intermediaries (Guo \& Iyer, 2013) or retailer-driven bundling and its effect on upstream channel members (Bhargava, 2012), so these may be useful for a modern concept of vertical structures to facilitate stronger governance of the chain. As more firms move to hybrid structures to deliver offerings to end users, research has followed suit and examined partially integrated vertical channels (Kim et al., 2011), which could be the same for chains. Neves (2008) proposed a sequence for creating a vertical organization in agribusiness chains that fits and may help the implementation. The method includes six phases for creating a vertical organization: propose the idea of a vertical organization, establish the organization formally, define the organization's funding mechanisms, form the board and set the operational structure, 
permanently increase the number of associates, and measure performance.

\section{Overcoming the Difficulties in Implementing the ChainPlan}

Several authors have studied factors that have led to the non-implementation of plans, such as Beer and Eisenstat (2000), Charan and Colvin (1999), David (2002), Giraldi and Campomar (2005), Klag and Langley (2014), Kaplan and Norton (1997, 2001, 2004, 2008), O’Regan and Ghobadian (2002), and Wessel (1993).

Ten years of experience in designing chain plans and facilitating implementation has led to several observations regarding the speed and success of implementation, including:

a) a lack of participant understanding of planning and strategy concepts;

b) not anticipating problems and conflicting priorities;

c) finding key volunteer leaders that are motivated;

d) inadequate leadership ability among the leaders;

e) a lack of discipline/motivation of members and organizations;

f) political and cultural issues among participants;

g) poor team integration;

h) different agents seeking their own objectives;

i) allowing some to believe they are owners of the collective;

j) a lack of understanding and clarity of goals and objectives;

k) a lack of established indicators to be monitored;

1) a lack of standards for implementation;

m) not creating a simplified version of the detailed plan that is communicated in an executive manner;

Addressing these points in advance, perhaps as part of stage 12, would enable ChainPlan and its strategic projects to make progress.

\section{Managerial Implications of this Article}

The ChainPlan method addresses the strategic planning and management of food and agribusiness chains. The method focuses on the general concern about the direction of a particular chain in the long term, the development of a viable and sustainable structure, the overall direction required to match its organization and development, the definition of objectives and collective actions, and evaluation metrics, from an overall perspective.

The ChainPlan method involves a number of advantages and opportunities, challenges, and additional difficulties for agents that intend to organize themselves in order to develop and implement a strategic planning and management process for a chain.

As possible advantages, it describes values and philosophies of the leaders of the chain, to guide a common future vision. The method also allows for the sharing of information and experience among agents. ChainPlan can identify opportunities for collective actions to improve the industry situation, enhance integration and efficiency in the supply chain, and identify opportunities for joint research activities, thus providing the vision of an applied netchain. The facilitation process can serve as an instrument for coordination, cooperation, integration, and enthusiasm in addressing common problems. Developing a strategic plan for the chain can create more flexibility in the face of unexpected changes and a more rigorous and professional collective chain regarding standards, budgets, the division of responsibilities, and schedules. Finally, the method can lead to social, environmental, and economic results that are more interesting for the chain as a whole.

The ChainPlan method is a theoreticalempirical method, built based on the academic literature and perfected over the years through its application in several productive chains. In each method application, new insights have emerged 
and are now incorporated in the version presented in this paper. The method seeks to address the theoretical gap relating to the strategic planning applied to agribusiness chains and especially the lack of a tool for applying strategic planning in this context. As discussed in this paper's literature review, many authors have proposed a method to build strategic plans in organizations, but when the subject involves planning agribusiness chains, the academic discussion revolves around agribusiness chain coordination and analyses to be applied in this sector. Thus, this article seeks to fill this theoretical gap and propose a tool, which is a specific strategic planning method for application in agribusiness chains.

\section{I Limitations of the research and the method}

The updated method is a simplification of the processes involved in the strategic planning and management of organizations. Additional important stages may have been missed in the method. In addition, the list of analyses provided in each stage are suggestions based on the authors' experiences in executing these stages; certainly, other analyses could be added to each stage. Despite our best efforts, the literature review may have missed important methods of strategic planning and management of chains. Finally, the simplicity with which we treat many of the subjects and the bias towards theory built based on application are other limiting factors of this method.

The ChainPlan method introduced here provides a rich platform for future studies. For example, there are many opportunities to develop and refine the analysis methods in many of the stages of the model. The opportunity exists to revisit the previously developed plans to rigorously measure the successes and shortcomings of their implementation. Finally, application of the method to additional chains in different countries and environments around the world would provide opportunities to continue to enhance the method while also benefitting the organizations and agents in those chains.

\section{References}

Andrews, K. R. (1987). The concept of corporate strategy (3rd ed.). Homewood, IL: Richard D. Irwin.

Ansoff, H. I. (1965). Corporate strategy: An analytic approach to business police for growth and expansion. New York: McGraw- Hill.

Antia, K. D., Zheng X., \& Frazier, G. (2013). Conflict management and outcomes in franchise relationships: The role of regulation. Journal of Marketing Research, 50(5), 577-89.

Arya, A., \& Mittendorf, B. (2011). Supply chains and segment profitability: How input pricing creates a latent cross-segment subsidy. The Accounting Review, 86(3), 805-824.

Backer, G. A. (2003). Strategic planning and financial performance in the food processing sector. Review of Agricultural Economics, 25(2), 470-482.

Bhargava, H. K. (2012). Retailer-driven product bundling in a distribution channel. Marketing Science, 31(6), 1014-21.

Batalha, M. O. (Ed.). (2009). Gestão agroindustrial (3a ed.). São Paulo: Atlas.

Beer, M., \& Eisenstat, R. (2000). The silent killers of strategy implementation and learning. Sloan Management Review, 41(4), 29-40.

Besanko, D., Dranove, D., \& Shanley, M. (2000). Economics of strategy. New York: John Wiley and Sons.

Buzzell, R. D., \& Ortmeyer, G. (1995). Channel partnership streamline distribution. Sloan Management Review, 36(3), 85-96.

Campomar, M.C. (1982). Contribuiçôes ao estudo de planejamento e confeç̧âo de planos em marketing: 
Uma aplicação em concessionárias de automóveis (Masters Dissertation). Faculdade de Economia, Administração e Contabilidade de Ribeirão Preto, Ribeirão Preto, SP, Brasil.

Chaddad, F., \& Rodriguez-Alcalá, M. E. (2010). Inter-organizational relationships in agrifood systems: A transaction cost economics approach. In C. Fischer, \& M. Hartmann (Eds.), Agrifood Chain Relationships (Cap. 2, pp. 45-60). Oxford, UK: Cab International.

Chandler, A. D. (1962). Strategy and structure. Cambridge: MIT Press.

Charan, R., \& Colvin, G. (1999). Why CEOs fail it's rarely for lack of smarts or vision: Most unsuccessful CEOs stumble because of one simple, fatal shortcoming. Fortune. Retrieved from https://archive.fortune.com/magazines/fortune/ fortune_archive/1999/06/21/261696/index.htm

Chintagunta, P. K., Chu J., \& Cebollada, J. (2011). Quantifying transaction costs in online/ off-line grocery channel choice. Marketing Science, 31(1), 96-114.

Clay, P. M., \& Feeney, R. (2019). Analyzing agribusiness value chains: A literature review. International Food and Agribusiness Management Review, 22(1), 31 - 46.

Coase, R. H. (1937). The nature of the firm. Economica, 4(16), 386-405.

Cook, M. L., \& Iliopoulos, C. (2016). Generic solutions to coordination and organizational costs: Informing cooperative longevity. Journal of Chain and Network Science, 16(1), 19-27.

Draganska, M., Klapper, D., \& Villas-Boas, S. B. (2010). A larger slice or a larger pie? An empirical investigation of bargaining power in the distribution channel. Marketing Science, 29(1), 57-74.

David, F. R. (2002). Strategic management: Concepts and cases (9th ed.). New Jersey: Prentice Hall.
Davis, J. H., \& Goldberg, R. A. (1957). A concept of agribusiness. Boston: Harvard University.

Digman, L. A. (1990). Strategic management: Concepts, decisions, cases (2nd ed.). Boston: BPI Irwin.

Farina, E. M. M. Q., Azevedo, P. F., de, \& Saes, M. S. M. (1997). Competitividade: Mercado, estado e organizaçóes. São Paulo: Singular.

Gilligan, C., \& Wilson, R. M. S. (2003). Strategic marketing planning. Linacre House: ButterworthHeinemann.

Giraldi, J. M. E., \& Campomar, M. C. (2005). Implementação eficaz de planos de marketing. Revista eletrônica de gestão de negócios, 1(3), 37-54. Retrieved from https://www.unisantos.br/mestrado/ gestao/egesta/artigos/43.pdf

Guerreiro, R., \& Souza, R. P. (2015). Um estudo sobre percepçóes de importância de atividades do processo de gestão e barreiras à implementação do planejamento estratégico. Revista Universo Contábil, 11(1), 88-104.

Guo, L., \& Iyer, G. (2013), Multilateral bargaining and downstream competition, Marketing Science, 32(3), 411-30.

Grant, R. M. (2010). Contemporary strategy analysis (7th ed.). Chichester: John Wiley \& Sons.

Guo, L., \& Iyer, G. (2010). Information acquisition and sharing in a vertical relationship. Marketing Science, 29(3), 483-506.

Heide, J.B., Wathne, K. H., \& Rokkan, A. I. (2007). Interfirm Monitoring, Social Contracts, and Relationship Outcomes. Journal of Marketing Research, 44(3), 425-433.

Henderson, B. D. (1984). The logic of business strategy. Cambridge: Ballinger.

Hill, C. W. L. (1990). Cooperation, opportunism and the invisible hand: Implications for transaction 
cost theory. Academy of Management Review, 15(3), 500-513.

Jain, S. C. (2000). Marketing planning \& strategy (6th ed.). Cincinnati: Thomson Learning.

Jap, S. D., Robertson, D. C., Rindfleisch A., \& Hamilton, R. (2013). Low-Stakes opportunism. Journal of Marketing Research, 50(1), 216-27.

Kaplan, R. S., \& Norton, D. P. (1992). The balanced scorecard: Measures that drive performance. Harvard Business Review, 70(1), 70-79.

Kaplan, R. S., \& Norton, D. P. (1997). A estratégia em ação: Balanced scorecard (14th ed.). Rio de Janeiro: Campus.

Kaplan, R. S., \& Norton, D. P. (2001). Organização orientada para a estratégia: como as empresas que adotam o balanced scorecard prosperam no novo ambiente de negócios. Rio de Janeiro: Campus.

Kaplan, R. S., \& Norton, D. P. (2004). Mapas Estratégicos: Convertendo ativos intangiveis em resultados tangiveis ( 7 th ed.). Rio de Janeiro: Elsevier.

Kaplan, R. S., \& Norton, D. P. (2008). A execução premium: A obtençâo da vantagem competitiva através do vinculo da estratégia com as operaçôes de negócios. Rio de Janeiro: Elsevier.

Kim, S. K., McFarland R. G., Kwon S., Son S., \& Griffith D. A. (2011). Understanding governance decisions in a partially integrated channel: A contingent alignment framework. Journal of Marketing Research, 48(3), 603-16.

Klag, M., \& Langley, A. (2014). Critical junctures in strategic planning: Understanding failure to enable success. Organizational Dynamics, 43(4), 274-283.

Krafft, M., Goetz, O., Mantrala, M., Sotgiu, F., \& Tillmans, S. (2015). The Evolution of Marketing Channel Research Domains and Methodologies:
An Integrative Review and Future Directions. Journal of Retailing, 91(4), 569-585.

Kotler, P. (2000). Administração de marketing: Análise, planejamento, implementação e controle. São Paulo: Prentice Hall.

Kozlenkova, I. V., Samaha, S. A., \& Palmatier, R. W. (2014). Resource-Based theory in marketing. Journal of the Academy of Marketing Science, 42(1), $1-21$.

Lambin, J. J. (2012). Market-driven management: Strategic and operational marketing (3rd ed.). United Kingdom: Palgrave Macmillan.

Lafley, A. G., \& Martin, R. L. (2013). Playing to win: How strategy really works. Boston: Harvard Business Press.

Las Casas, A. L. (1999). Plano de marketing para micro e pequena empresa. São Paulo: Atlas.

Lazzarini, S. G., Chaddad, F. R., \& Cook, M. (2001). Integrating supply and network analysis: The study of netchains. Journal on Chain and Network Science, 1(1), 7-22.

Lusch, R.F., \& Brown, J. R. (1996). Interdependency, contracting and relational behavior in marketing channels. Journal of Marketing, 60(4), 19-38.

McNeil, I.R. (1974). The many futures of contracts. Southern California Law Review, 47(3), 691-816.

Ménard, C. (2002). The economics of hybrid organizations. Paris: MIT.

Mintzberg, H., Quinn, J. B., \& James, R. M. (1988). The strategy process: Concepts, contexts and cases. Englewood Cliffs, NJ: Prentice-Hall.

Mintzberg, H. (1994). The fall and rise of strategic planning. Harvard Business Review. Retrieved from https://hbr.org/1994/01/the-fall-and-rise-ofstrategic-planning 
Moore, J. L. (1993). Writers on strategy and strategic management. London: Penguin Books.

Morvan, Y. (1985). Fondements d'economie industrielle. Paris: Econômica.

Nassar, A. M., \& Zylberszajn, D. (2004). Associaçôes de interesse no agronegócio brasileiro: Análise de estratégias coletivas. Revista de Administração da Universidade de São Paulo, 39(2), 141-152.

Neves, M. F. (2005). Planejamento e gestão estratégica de marketing. São Paulo: Atlas.

Neves, M. F. (2008). Método para planejamento e gestão estratégica de sistemas agroindustriais (GESis). Revista de Administração da Universidade de São Paulo, 43(4), 331-343.

Nijs, V. R., Misra, K., \& Hansen, K. (2013). Outsourcing retail pricing to a category captain: The role of information firewalls, Marketing Science, 33(1), 66-81.

Oliveira, D. P. R. (2006). Planejamento estratégico: Conceitos, metodologia e práticas (6a ed.). São Paulo: Atlas.

Olson, M. (1999). A lógica da açâo coletiva: Os benefícios públicos e uma teoria dos grupos sociais. São Paulo: EDUSP.

Omta, S. W. F., Trienekens, J. H., \& Beers, G. (2001). Chain and network science: A research framework. Journal on Chain and Network Science, 1(1), 1-6.

O'regan, N., \& Ghobadian, A. (2002). Formal strategic planning: The key to effective business process management? Business Process Management Journal, 8(5), 416-429.

Palmatier, R. W., Houston, M. B., Dant, R. P., \& Grewal, D. (2013). Relationship velocity: toward a theory of relationship dynamics. Journal of Marketing, 77(1), 13-30.
Pearce II, J.A., \& Robinson, R.B., (2014) Strategic management: Strategy formulation and implementation control (14th ed.). New York: Mcgraw Hill Education.

Porter, M. E. (1980). Competitive strategy: Techniques for analyzing industries and competitors. New York: Free Press.

Prahalad, C. K., \& Hamel, G. (1990, May-June). The core competence of the corporation. Harvard Business Review.

Richey, G. R., Jr., Tokman M., \& Dalela, V. (2010). Examining collaborative supply chain service technologies: A study of intensity, relationships and resources, Journal of the Academy of Marketing Science, 38(1), 71-89.

Rigby, D., \& Bilodeau, B. (2015, June 10). Management tools \& trend 2015. Bain \& Company. Retrieved from https:/www.bain.com/ insights/management-tools-and-trends-2015

Rindfleisch, A., \& Heide, J. B. (1997). Transaction cost analysis: Past, present and future applications. Journal of Marketing, 61(4), 30-54.

Rodriguez, A., Nieto, (2016, December 13). How to prioritize your company's projects. Harvard Business Review.

Sacomano, M., Neto, \& Truzzi, O. M. S. (2004). Configurações estruturais e relacionais da rede de fornecedores: Uma resenha compreensiva. Revista de Administração da Universidade de São Paulo, 39(3), 255-263.

Samaha, S. A., Palmatier R. W., \& Dant, R. P. (2011). Poisoning relationships: Perceive unfairness in channels of distribution. Journal of Marketing, 75(3), 99-117.

Silva, A. L., da., \& Batalha, M. O. (2010) Marketing estratégico aplicado ao agronegócio. In M. O. Batalha (Ed.), Gestão agroindustrial (3a ed., Vol. 1, pp. 113-183). São Paulo: Atlas. 
Soriano, R. L., Torres, M. J. M., \& Rosaleñ, R. C. (2010). Methodology for sustainability strategic planning and management. Industrial Management \& Data Systems, 110(2), 249-268.

Spralls, S. A., III, Hunt, S. D., \& Wilcox, J. B. (2011). Extranet Use and Building Relationship Capital in Interfirm Distribution Networks: The Role of Extranet Capability. Journal of Retailing, 87(1), 59-74.

Steenkamp, J-B. E. M. \& Geyskens, I. (2012). Transaction cost economics and the roles of national culture: A test of hypotheses based on Inglehart and Hofstede. Journal of the Academy of Marketing Science, 40(2), 252-70.

Thompson, A. A., \& Strickland, A. J. (2000). Planejamento estratégico: Elaboração, implementação e execução. São Paulo: Pioneira.

Wang, D. T., Gu F. F., \& Dong, M. C. (2013). Observer effects of punishment in a distribution network. Journal of Market Research, 50(5), 627-43.

Watson, G. F., IV, Worm, S., Palmatier, R. W., \& Ganesan, S. (2015). The evolution of marketing channels: Trends and research directions. Journal of Retailing, 91(4), 546-568.

Wernerfelt, B. (1984). A resource-based view of the firm. Strategic Management Journal, 5(2), 171-180.
Wessel, J. R. (1993). The strategic human resource management process in practice. Planning Review, 21(5), 37-39.

Westwood, J. (1995). Plano de marketing. Sáo Paulo: Makron Books.

Williamson, O. E. (1985). The economic institutions of capitalism. New York: Free Press.

Wood, M. B. (2004). Marketing planning: Principles into practice. Harlow: Prentice Hall.

Wright, P., Kroll, M. K., \& Parnell, J. (2000). Administração estratégica: Conceitos. São Paulo: Atlas.

Zylbersztajn, D. (1996). Entre o mercado e a hierarquia: análise de casos de quebra contratual no agribusiness. Estudos temáticos. São Paulo: PENSA.

Zylbersztajn, D., \& Farina, E. M. M. Q. (1999). Strictly coordinated food-systems: Exploring the limits of the Coasian firm. International Food and Agribusiness Management Review, 2(2), 249-265. Zylbersztajn, D., \& Neves, M. F. (Ed.). (2000). Economia e gestão dos negócios agroalimentares. São Paulo: Pioneira. 
About the Authors:

1. Marcos Fava Neves, Titular Professor (part time) at University of São Paulo and Fundação Getulio Vargas, Ribeirão Preto, Brazil. E-mail: favaneves@gmail.com

ORCID

(iD)0000-0002-5693-7543

2. Rafael Bordonal Kalaki, PhD in Business Administration at University of São Paulo and CEO at Socicana, Ribeirão Preto, Brazil. E-mail: rbkalaki@gmail.com

ORCID

(iD)0000-0003-1730-3641

3. Jonny Mateus Rodrigues, $\mathrm{PhD}$ student in Business Administration at University of São Paulo, Ribeirão Preto, Brazil. E-mail: jonnymateus@usp.br

\section{ORCID}

(iD 0000-0002-4301-7553

4. Allan Wayne Gray, Professor, Director of MS/MBA in Food and AgriBusiness, and Land O'Lakes Chair in Food and Agribusiness at Purdue University, West Lafayette, USA. E-mail:gray@purdue.edu ORCID

(iD 0000-0002-9590-6985

\section{Contribution of each author}

Each author should take responsibility for at least one component of the paper. If the article is approved for publication, the authors should indicate in the diagram below, what was the contribution of each.

\begin{tabular}{|c|c|c|c|c|}
\hline Contribution & $\begin{array}{l}\text { Marcos Fava } \\
\text { Neves }\end{array}$ & $\begin{array}{l}\text { Rafael Bordonal } \\
\text { Kalaki }\end{array}$ & $\begin{array}{l}\text { Jonny Mateus } \\
\text { Rodrigues }\end{array}$ & $\begin{array}{l}\text { Allan Wayne } \\
\text { Gray }\end{array}$ \\
\hline 1. Definition of research problem & $\sqrt{ }$ & & & \\
\hline $\begin{array}{l}\text { 2. Development of hypotheses or research questions } \\
\text { (empirical studies) }\end{array}$ & $\sqrt{ }$ & & & \\
\hline 3. Development of theoretical propositions (theoretical work) & $\sqrt{ }$ & $\sqrt{ }$ & $\sqrt{ }$ & \\
\hline 4. Theoretical foundation/Literature review & $\sqrt{ }$ & $\sqrt{ }$ & $\sqrt{ }$ & \\
\hline 5. Definition of methodological procedures & $\sqrt{ }$ & $\sqrt{ }$ & & \\
\hline 6. Data collection & $\sqrt{ }$ & $\sqrt{ }$ & & \\
\hline \multicolumn{5}{|l|}{ 7. Statistical analysis } \\
\hline 8. Analysis and interpretation of data & $\sqrt{ }$ & $\sqrt{ }$ & & \\
\hline 9. Critical revision of the manuscript & $\sqrt{ }$ & $\sqrt{ }$ & $\sqrt{ }$ & $\sqrt{ }$ \\
\hline 10. Manuscript writing & $\sqrt{ }$ & $\sqrt{ }$ & $\sqrt{ }$ & $\sqrt{ }$ \\
\hline 11. Other (please specify which) & & & & \\
\hline
\end{tabular}

This information will be available in publications as an end notal in accordance with the criteria, policies and procedures for admission and permanence of scientific journals in SciELO Brazil Collection.

\section{Erratum}

Where was written:

“Review of Business Management, São Paulo, v.21, n.4, p.628-646, oct/dec. 2019”

Now read:

“Rev. Bras. Gest. Neg. São Paulo v.21, Special Issue. 2019 p. 628-646” 